UDC 366.1:338.488

JEL Classification: F02; F51; F53; E64

KULYK Mariia,

$\mathrm{PhD}$ (Economics), Associate Professor,

Associate Professor at the Department

of Hotel and Restaurant Business

Kyiv National University

of Trade and Economics

19, Kioto str., Kyiv, 02156, Ukraine

E-mail:m.kulyk@knute.edu.ua ORCID ID:0000-0001-8732-7441
DOI: http://doi.org/10.31617/visnik.knute.2021(138)08

KOMPANETS Kateryna,

$\mathrm{PhD}$ (Economics), Associate Professor, Associate

Professor at the Department

of Hotel and Restaurant Business

Kyiv National University

of Trade and Economics

19, Kioto str., Kyiv, 02156, Ukraine

E-mail:k.kompanets@knute.edu.ua ORCID ID:0000-0002-7189-2355

\author{
AVDAN Oksana, \\ $\mathrm{PhD}$ (Economics), Associate Professor \\ at the Department of Hotel and Restaurant Business \\ Kyiv National University of Trade and Economics \\ 19, Kioto str., Kyiv, 02156, Ukraine \\ E-mail: o.avdan@knute.edu.ua \\ ORCID ID:0000-0003-1868-4685
}

\title{
MANAGEMENT OF CONSUMERS BEHAVIOR OF HOSPITALITY SERVICES
}

The article considers the consequences of the Covid-19 pandemic on the activities of hospitality enterprises. The main determinants that changed consumer behavior under quarantine restrictions were identified. It was determined that scientific works did not study methods of researching consumer loyalty in crisis conditions. This gave reason to establish the purpose and objectives of the article and to prove the need to apply the proposed universal method of identifying consumer satisfaction level with hospitality services.

Keywords: hospitality enterprises, consumer, consumer satisfaction level, consumer behavior, the Covid-19 pandemic.

Background. The world is in an economic crisis caused by the COVID-19 pandemic. All sectors of the economy were affected. One of the most affected by quarantine restrictions is tourist, resort, recreational and health facilities (hotels, camps, sanatoriums, boarding houses, health complexes), which have almost completely ceased their activities. According to the latest research of the National Institute for Strategic Studies [1], in 2020 the volume of international tourism revenues is set at 58-78\% compared to 2019. According to the experts, the recovery of demand to the level of 2019 will take at least two years. This situation increases competition level between hospitality establishments and intensifies personal warfare for each client today. This leads to a constant search for alternative ideas that will meet the consumers' needs. The sense of security that has flooded the world and shaped everyone's lifestyle has led to the transformation of a new consumer type. In fact, there is now a new digital stratification of society. 
And so it becomes difficult to assess and manage consumer behavior. It is almost impossible to assess their level of satisfaction and form a base of loyal consumers. This problem solving requires appropriate research and scientific substantiation of theoretical and methodological aspects of consumer behavior management in the COVID-19 pandemic. That's why it is necessary to form a new method of modern consumers' behavior assessment, which will help hospitality companies to build their crisis strategy to overcome the pandemic crisis.

Analysis of recent research and publications. Critical analysis of scientific papers on the formation of close relations with consumers of hospitality enterprises and consumer behavior management allows us to state that in the scientific area it formed important theoretical and methodological provisions that determine the essence of this process and its implementation features. In particular, a significant contribution to the development of the theory and practice of relations management with hospitality services consumers is in the works of domestic scientists A. Mazaraki, M. Boiko, A. Okhrimenko [2], O. Kalieva, I. Taranukha [3], A. Lankov, M. Sheptukhin [4], D. Semenda, O. Semenda [5], I. Senenko [6], O. Yevtushevska [7]. D. Semenda, O. Semenda investigated consumer behavior in modern market conditions and proposed approaches to consumer behavior modeling. O. Yevtushevska studied the peculiarities of consumer behavior in the modern market and identified the main types of individuals. The works of O. Kaliev, I. Taranukha, M. Sheptukhin are devoted to consumer behavior modeling. A. Mazaraki, M. Boiko, A. Okhrimenko foresaw development of the national tourism system and touched on the general issues of customer service in the hospitality sector. I. Senenko offered conceptual approach to the formation of the mechanism of management hospitality services of consumer behavior. A. Lankov took up the question of VIP client management. But the issues of assessment of the consumer satisfaction level of with the consumption of hospitality services remain unsolved. Despite significant scientific achievements in the field of consumer behavior research, hospitality services remain unsolved with many theoretical and applied problems. A special feature of scientific research is the definition and management of consumer behavior in stable economic conditions. But the restructuring in the hospitality industry presents new challenges for determining the characteristics of the pandemic consumer and defining its relationship with hospitality in quarantine.

The issue of enterprise management during the COVID-19 pandemic has captured the scientific world. Important scientific achievements on the study of this problem are in the papers of domestic and foreign scientists L. Bovsh, L. Hopkalo, I. Komarnytskyi [8], G. George, P. Puranam, K. Lakhani [9], K. Heinonen, T. Strandvik [10], Y. Gorbenko, L. Litvyshko [11] and the others. L. Bovsh, L. Hopkalo, I. Komarnytskyi considered scientific substantiation of compliance of hotel business in pandemic conditions and gave the characteristics of changes in the consumption of hospitality services. 
L. Litvishko, Y. Gorbenko analyzed adaptation of business to the new realities of the COVID-19 pandemic. G. George, K. Lahani and P. Puranam raised the issue of changes in consumer types, which were caused by the challenges of the pandemic crisis. K. Heinonen and T. Strandwick studied reformatting innovation in services: COVID-19 as a catalyst for imposed innovation in services. The problem of the economic crisis and the question of the way out of it of enterprises are revealed in the works of the above mentioned authors. At the same time, there are few publications in the available literature that identify areas for measures to assess and manage consumer behavior, although this is the key to competitiveness and recovery of the pandemic crisis. Therefore, it becomes necessary to comprehend the theoretical issues of managing the behavior of hospitality services consumers in a pandemic crisis.

The aim of the article is to form an innovative method of determining the satisfaction level of hospitality consumers, to identify the types of consumers that have evolved in the COVID-19 pandemic.

Materials and methods. The information base of the study is the publications of domestic scientists on the problems of managing consumer behavior in the COVID-19 pandemic. Methods of systematization, analysis and synthesis, graphical, tabular were used.

Results. In the situation of economic competition of hospitality enterprises for markets, the importance of high communication activity and effective interaction with consumers will increase. The thesis that the functioning of the enterprise depends on the preventive recognition and understanding of the needs of existing and potential consumers is important in this context [2]. Now it is the establishment of close relations with consumers and the formation of commitment to hospitality services that is an important determinant for the enterprises survival in a pandemic crisis.

The COVID-19 pandemic has severely disrupted global consumption, forcing people not to break old habits and adopt new ones. Companies that seek to emerge from the crisis in stronger positions need to develop a systematic understanding of changing habits. For many enterprises, it requires a new process of identifying and evaluating change before it becomes apparent to all [11].

Therefore, the company needs to monitor constantly information about customer satisfaction, identifying ways to obtain this information, in time to develop measurement methods and analyze the information obtained in order to meet the demands and expectations of consumers [3].

In Ukraine, the official point of view on the term "customer satisfaction" is defined by the National Standard of Ukraine DSTU ISO 10004: 2013 "Customer Satisfaction. Guidelines for Monitoring and Evaluation" (ISO 10004: 2012, IDT), according to which customer satisfaction is "perception by the customer of the level of satisfaction of his expectations" [12, p. 2]. 
To assess the level of consumer satisfaction with services, the main problem is the choice of method of collecting information about the consumer. Quantitative (objective) and qualitative (subjective) methods are used to collect information (figure). Existing methods are aimed at identifying the general characteristics of the success of the enterprise and assess the satisfaction of consumers of food products in their purchases, and are based on changes in the financial performance of the enterprise. It becomes necessary to create a universal method of assessing the level of satisfaction of service consumers who are waiting for a certain level of service.

The level of consumer satisfaction of the enterprise is influenced by the evaluation criteria: the reliability of the hospitality enterprise, the range of services, their cost, the ability to use various loyalty programs; speed and quality of service; competence and professionalism of the staff.

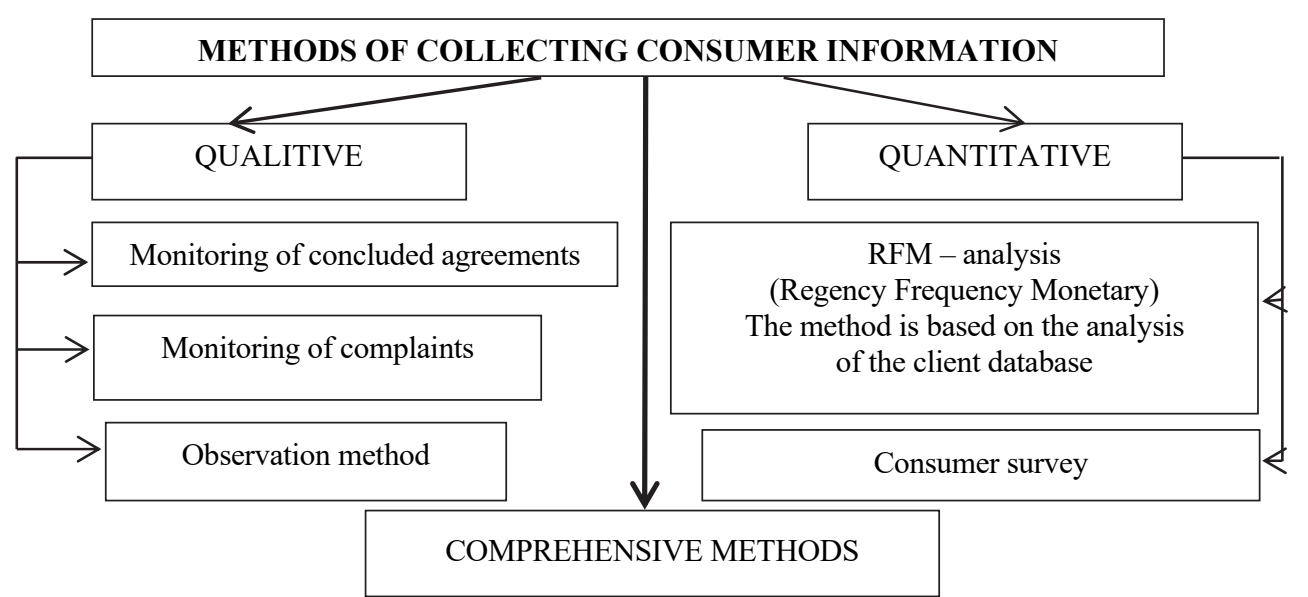

Customer Satisfaction Index (CSI) Gives opportunities:

how the customer is satisfied with a particular process, service or product of the enterprise; how much the client is satisfied with the enterprise in general; how the customer is satisfied with the interaction with a competitor

American Consumer Satisfaction Index (ACSI)

Shows the rating of the enterprise, which is based on the analysis of desires and expectations of the consumer, how he perceives the price and quality

CES and SCI Customer Effort Score Indices

Allows you to analyze the level of effort of the client, which he needs to make to resolve their

\section{Methods of consumer satisfaction measuring}

Source: developed by the authors. 
All methods that are presented in Figure, it is advisable to use in hospitality enterprises to identify the target loyal consumer. Such methods are directly appropriate and they are possible only in direct contact with the client and allow you to form a direct relationship with him. But in modern conditions, the possibility of direct communication in the field of hospitality is limited. Therefore, an innovative method of assessing the level of consumer satisfaction (LCS) is needed, which will cover as much as possible the channels of interaction between the consumer and the hospitality enterprise. The basis of LCS is the communication of customers on the main site of the enterprise. Thus, the main criteria for determining the target loyal customers will be quantitative:

- number of site visits $(n)$;

- number of orders $(n z)$;

- cost of the order (bi);

- number of positive feedback $(p)$.

- number of refusals to receive services $(d)$;

Site monitoring for these indicators should be carried out at monthly intervals. Thus, with the help of these indicators it is possible to identify consumers by categories: permanent, potential and loyal, neutral. Companies can provide information only about customers who have made orders and registered at least once working with the database of the hospitality website, it is impossible to identify consumers who simply visit the site and do not leave messages or feedback.

An important issue in conducting this type of marketing research is the choice of the scale type for quantifying consumer satisfaction. Methods of CSI, NPS and ACSI use a scale from 1 to 10; it is advisable to measure LCS on the same scale.

Such division can be made in three stages to form a management mechanism in accordance with the stages of consumer behavior of hospitality services, conventionally: behavior before the consumption of services (accommodation), during consumption, after consumption. According to these stages, it is proposed to identify 3 roles of consumers of hospitality services:

- potential customers;

- guests;

- customers.

A potential customer is a consumer who has not used the services of a particular company, or has tried only once and has not clearly defined its attitude to the service provided [6].

Some authors $[4 ; 7]$ consider that the customer and the guest are differrent roles of the consumer. A guest is a consumer who is living now in a hotel or other accommodation, or is in a restaurant. A customer is a consumer who has used the services of one specific hospitality company more than once. Based on these definitions and conditional transformations into consumer behavior, it is necessary to work with the client through Internet channels. 
Therefore, it is proposed to check the site on a monthly basis, so the critical number of the maximum contact is 30 , which in turn will be equal to 10 points. We have identified four types of consumers and another category that we cannot directly influence - neutral consumers. Therefore, we can make a matrix of consumer identification (table).

Table

\section{Consumer identification matrix}

\begin{tabular}{|l|c|c|}
\hline \multicolumn{1}{|c|}{ Consumer identification } & Assessment level, $x_{i}$ & Weighting factor, $k_{i}$ \\
\hline Permanent & $10-8$ & 1 \\
\hline Potential & $7-5$ & 0.8 \\
\hline Loyal & $4-2$ & 0.6 \\
\hline Neutral & $1-0$ & 0.4 \\
\hline
\end{tabular}

Source: developed by the authors.

To form an economic-mathematical model, we introduce the notation:

$x_{i}-$ is the intensity of the $i$-th action (binary variable, 10 or 0 );

$k_{i}$-is the rate of significance for the $i$-th action, which determines the loyalty of the target - identified consumer (equal to the weight of significance). Thus, to develop a matrix for determining the level of criteria, it is necessary to sort each negative and positive consumer feedback by assessment levels (Table);

$z_{i}-$ is the increase in satisfaction with the implementation of the $i$-th planned event, points;

$b_{i}-$ is the costs for the implementation of the $i$-th planned measure, monetary units;

$\sigma_{i}-$ is the standard deviation of the increase in satisfaction with the implementation of the $i$-th planned event, points;

$\Delta-$ is the target increase in satisfaction with the introduction of the optimal set of planned activities, points, $\Delta=$ Zgoal - Zfact;

Zfact, Zgoal - is the actual and target value of the integrated indicators of satisfaction.

The mathematical model of the level of satisfaction of consumers of hospitality services has the form:

$$
\sum_{i}^{\prime} k_{i} z_{i} x_{i} \geq \Delta .
$$

This inequality shows the most probable level of consumer satisfaction.

Determining the level of monetary contribution to increase consumer satisfaction is calculated by the following mathematical model.

$$
\sum_{i} b_{i} x_{i} \leq V ; \quad \Sigma_{i} \sigma_{i} x_{i} \rightarrow \mathrm{min},
$$

where $V$ - is the amount in cash equivalent separated by the company to increase customer satisfaction.

Based on inequality, the total increase in satisfaction with the implementation of the optimal set of planned measures should be at least the target increase, the cost of implementing measures should not exceed the planned budget, and first of all measures will be selected for implementtation, respondents are most consistent. 
Creating an interactive method of detecting the level of customer loyalty (LCL) introduced additional parameters for quantifying customer satisfaction then; the formula of the mathematical model of the general level of LCL will look like this:

$$
L C L=\left\{\begin{array}{c}
\sum_{i} n i, n z \rightarrow \max ; \\
\sum_{i} \sigma_{i} x_{i} \rightarrow \min _{;} \\
\sum_{i} n z \times b i \geq d ; \\
\sum_{i} n i \times n z \times b i-p
\end{array} .\right.
$$

This is a universal mathematical model for assessing the level of consumer satisfaction, which is inherent in today's realities of hospitality.

Conclusion. That is, the COVID-19 pandemic has caused global changes between the hospitality-consumer relationships. Against the background of the development of modern digital and Internet technologies, the effectiveness of traditional marketing tools is declining. This transformation has become an obstacle to identifying major behavioral changes in the consumer. It is communication with which has become a secure form of communication and, as a consequence, the formation and maintenance of competitive advantages based on the technological advantages of communication channels. Therefore, it becomes difficult to assess the level of customer satisfaction, and this is an important determinant for determining the areas of close relationships with different types of consumers. That is, the proposed interactive method of identifying the level of customer loyalty will help hospitality companies in post-conduct conditions to strengthen their competitive position and get out of crisis.

\section{REFERENCES}

1. National Institute for Strategic Studies. Regarding the development of tourism in Ukraine in the conditions of increased epidemic risks.niss.gov.ua. Retrieved from https://niss.gov.ua/sites/default/files/2020-06/turyzm-v-ukraini.pdf20 [in English].

2. Mazaraki, A. A., Boyko, M. G., \& Ohrimenko, A. G. (2018). Forsajt rozvytku nacional'noi'turystychnoi'systemy [Foresight development of the national tourism system] Visn. Kyiv. nac. trade and economy un-tu - Herald Kyiv National University of Trade and Economics, 3, 5-22 [in Ukrainian].

3. Kalieva, O. M., Taranukha, I. A., \& Sheptukhin, M. V. (2016). Modelirovanie povedeniia potrebitelei kak instrument effektivnoho upravleniia marketinhom $\mathrm{v}$ klientoorientirovannoi orhanizatsii [Modeling of consumer behavior as a tool for effective marketing management in a customer-oriented organization]. Economics, Sociology and Law, 11, 27-33[in Ukrainian].

4. Lan'kov, A. N. (2015). Shcho take prestyzhne spozhyvannia v Pivnichnii Korei [What is prestigious consumption in North Korea]. Retrieved from http://carnegieendowment.org (accessed: 02.04.2021) [in Ukrainian]. 
5. Semenda, D. K., \& Semenda, O. V. (2018). Doslidzhennia povedinky spozhyvachiv $\mathrm{v}$ suchasnykh rynkovykh umovakh [Study of consumer behavior in modern market conditions]. Young scientist, 1(53), 535-540. Retrieved from http://molodyvcheny.in.ua/ files/journal/2018/1/126.pdf (accessed: 02.03.2021) [in Ukrainian].

6. Senenko, I. A. (2015). Kontseptualnyi pidkhid do formuvannia mekhanizmu upravlinnia povedinkoiu spozhyvacha posluh hostynnosti [Conceptual approach to the formation of the mechanism of management of consumer behavior of hospitality services]. Effective economy, 10. Retrieved from http://www.economy.nayka.com.ual ?op $=1 \& \mathrm{z}=4414$ (accessed: 12.04.2021)[in Ukrainian].

7. Yevtushevska, O. V. (2016). Osoblyvosti povedinky spozhyvachiv na rynku $\mathrm{v}$ suchasnykh umovakh [Features of consumer behavior in the market in modern conditions]. Economics. Investments: practice and experience, 20, 22-25[in Ukrainian].

8. Bovsh, L., Hopkalo, L., \&Komarnytsky, I. (2020). Naukove obgruntuvannia vidpovidnosti hotelnoho biznesu $\mathrm{v}$ pandemichnykh umovakh [Scientific substantiation of compliance of hotel business in pandemic conditions]. Restaurant and hotel consulting. Innovations, 2, 166-181. DOI: 10.31866/2616-7468.3.2.2020.219691 [in Ukrainian].

9. George, G., Lahani, K. R., \& Puranam, P. (2020). Shcho zminylosia? Vplyv pandemii Covid na poriadok dennyi doslidzhen upravlinnia tekhnolohiiamy ta innovatsiiamy [What has changed? The impact of the Covid pandemic on the technology and innovation management research agenda]. Journal of Management Research, 57 (8), 1754-1758 [in Ukrainian].

10. Heinonen, K. \& Strandwick, T. (2020). Pereformatuvannia innovatsii v posluhakh: COVID-19 yak katalizator naviazanykh innovatsii u sferi posluh [Reformatting innovation in services: COVID-19 as a catalyst for imposed innovation in services]. Service Management Journal [in English].

11. Litvishko, L. O, \& Gorbenko, Yu. A. (2020). Adaptatsiia biznesu do novykh realii pandemii COVID-19 [Adaptation of business to the new realities of the COVID-19 pandemic]. Proceedings of the All-Ukrainian scientific-practical conference "Management and administration in the context of combating hybrid threats to national security" In the framework of the Erasmus + project "Academic counteraction to hybrid threats" WARN 610133-EPP-1-2019 FI-EPPKA2CBHE-JP, 65. Retrieved from https://drive.google.com/file/d/1k3PeCfr 7sJJogv8VydUQn4vwRAqT7xE/view 2 (accessed: 02.01.2021) [in Ukrainian].

12. DSTU ISO 10004: 2013 (2014). Customer Satisfaction. Guidelines for Monitoring and Evaluation (ISO 10004: 2012, IDT). Ministry of Economic Development of Ukraine Kyiv, 24, 117 [in Ukrainian].

The article was received by the editors 12.05.2021.

Кулик М., Компанець К., Авдан О. Управління поведінкою споживачів послуг гостинності.

Постановка проблеми. В умовах кризи, спричиненої пандемією COVID-19, найбільш постраждав сектор гостинності, що підвищує рівень конкурентної боротьби. Пандемія змінила типових споживачів, і тому управління поведінкою споживачів стало досить складним. Це вимагає теоретичної підготовки та формулювання методів оцінки рівня задоволеності в сучасних пандемічних умовах.

Метою статті є формування інноваційного методу визначення рівня задоволеності споживачів підприємств гостинності та типів споживачів, які еволючіонували в контексті пандемії COVID-19. 
Матеріали та методи. Інформаційною базою дослідження є публікації вітчизняних вчених з проблем управління поведінкою споживачів у контексті пандемії COVID-19. Використано методи систематизації, аналізу та синтезу, графічні, табличні та ін.

Результати дослідження. Визначено основні детермінанти, щуо змінили поведінку споживачів в умовах викликів карантинних обмежень. На підставі ивого розроблено інноваційний метод оцінки рівня задоволеності споживачів. Для реалізації методу запропоновано додаткові параметри кількісної оцінки лояльності гостя готелю та розроблено універсальну математичну модель загального рівня задоволеності споживачів.

Висновки. Оцінка рівня задоволеності клієнтів є важливим детермінантом для визначення напрямів комериійних взаємовідносин з різними типами споживачів. Запропонований інтерактивний метод виявлення рівня лояльності клієнтів допоможе підприємствам гостинності в постковідних умовах посилити конкурентні позийї і вийти з кризи.

Ключові слова: підприємства гостинності, споживач, рівень задоволеності споживачів, поведінка споживачів, пандемія COVID-19. 